\title{
Adsorption Removal of Environmental Hormones of Dimethyl Phthalate Using Novel Magnetic Adsorbent
}

\author{
Chia-Chi Chang, ${ }^{1}$ Jyi-Yeong Tseng, ${ }^{1}$ Dar-Ren Ji, ${ }^{1}$ Chun-Yu Chiu, ${ }^{2}$ \\ De-Sheng Lu, ${ }^{1}$ Ching-Yuan Chang, ${ }^{1,3}$ Min-Hao Yuan, ${ }^{1,4}$ Chiung-Fen Chang, \\ Chyow-San Chiou, ${ }^{6}$ Yi-Hung Chen, ${ }^{4}$ and Je-Lueng Shie ${ }^{6}$ \\ ${ }^{1}$ Graduate Institute of Environmental Engineering, National Taiwan University, Taipei 106, Taiwan \\ ${ }^{2}$ Department of Cosmetic Science and Application, Lan-Yang Institute of Technology, Yilan 261, Taiwan \\ ${ }^{3}$ Department of Chemical Engineering, National Taiwan University, Taipei 106, Taiwan \\ ${ }^{4}$ Department of Chemical Engineering and Biotechnology, National Taipei University of Technology, Taipei 106, Taiwan \\ ${ }^{5}$ Department of Environmental Science and Engineering, Tunghai University, Taichung 407, Taiwan \\ ${ }^{6}$ Department of Environmental Engineering, National I-Lan University, Yilan 260, Taiwan
}

Correspondence should be addressed to Ching-Yuan Chang; cychang3@ntu.edu.tw

Received 13 January 2015; Accepted 16 June 2015

Academic Editor: Zulin Zhang

Copyright (C) 2015 Chia-Chi Chang et al. This is an open access article distributed under the Creative Commons Attribution License, which permits unrestricted use, distribution, and reproduction in any medium, provided the original work is properly cited.

\begin{abstract}
Magnetic polyvinyl alcohol adsorbent M-PVAL was employed to remove and concentrate dimethyl phthalate DMP. The M-PVAL was prepared after sequential syntheses of magnetic $\mathrm{Fe}_{3} \mathrm{O}_{4}(\mathrm{M})$ and polyvinyl acetate (M-PVAC). The saturated magnetizations of M, M-PVAC, and M-PVAL are 57.2, 26.0, and $43.2 \mathrm{emu} \mathrm{g}^{-1}$ with superparamagnetism, respectively. The average size of M-PVAL by number is $0.75 \mu \mathrm{m}$ in micro size. Adsorption experiments include three cases: (1) adjustment of initial $\mathrm{pH}\left(\mathrm{pH}_{0}\right)$ of solution to 5 , (2) no adjustment of $\mathrm{pH}_{0}$ with value in 6.04-6.64, and (3) adjusted $\mathrm{pH}_{0}=7$. The corresponding saturated amounts of adsorption of unimolecular layer of Langmuir isotherm are 4.01, 5.21, and $4.22 \mathrm{mg} \mathrm{g}^{-1}$, respectively. Values of heterogeneity factor of Freundlich isotherm are 2.59, 2.19, and 2.59 which are greater than 1, revealing the favorable adsorption of DMP/M-PVAL system. Values of adsorption activation energy per mole of Dubinin-Radushkevich isotherm are, respectively, of low values of 7.04, 6.48, and $7.19 \mathrm{~kJ} \mathrm{~mol}^{-1}$, indicating the natural occurring of the adsorption process studied. The tiny size of adsorbent makes the adsorption take place easily while its superparamagnetism is beneficial for the separation and recovery of micro adsorbent from liquid by applying magnetic field after completion of adsorption.
\end{abstract}

\section{Introduction}

Emerging contaminants (ECs), such as hormones, have spread in various environmental media due to wide use of materials or products containing these substances or compounds. Most of these contaminants were discharged into aquatic environments [1-16]. The ECs were also found in sediments $[1,6,8,17,18]$, soil $[8,9,19]$, air [20,21], waste [19], and biota $[1,22,23]$. There has been a great ongoing concern, even at trace levels, on their potential, adverse effects on human health and ecological systems affecting biological and cell mechanisms $[1,3,9,11-13,15,24]$. Among the environmental hormones encountered, phthalate acid esters or phthalate esters (PAEs) have drawn much attention [18, 20, 21, 25-30].

PAEs are derivatives of phthalate acid. They have been applied for the manufacturing of polyvinyl chloride (PVC), polypropylene (PP), polyethylene (PE), and polystyrene (PS) and used as plasticizer, binder, and coating and printing ink $[21,27]$. Due to their endocrine disruption effects, many countries have either regulated the upper limiting concentration or restricted the use of PAEs in plastic toys. The contaminated sources include plastics factories, industrial and domestic wastewater treatment plants, landfills, reviver sediment, and sewage sludge $[18,20,25,27-30]$. The solubility of PAEs 
in water is low. Among the commonly used PAEs, dimethyl phthalate (DMP) has the solubility in water of $4000 \mathrm{mg} \mathrm{L}^{-1}$ or $0.4 \%$ [31], which is comparatively higher than most of other PAEs such as di-ethyl phthalate (DEP) $\left(1080 \mathrm{mg} \mathrm{L}^{-1}\right)$, di-hexyl phthalate (DHP) (slightly soluble with $0.05 \%$ or $\left.500 \mathrm{mg} \mathrm{L}^{-1} \max \right)$, di-n-butyl phthalate (DBP) $\left(13 \mathrm{mg} \mathrm{L}^{-1}\right)$, benzyl butyl phthalate (BBP) $\left(2.69 \mathrm{mg} \mathrm{L}^{-1}\right)$, di-(2-ethyl hexyl) phthalate (DEHP) $\left(0.3 \mathrm{mg} \mathrm{L}^{-1}\right)$, di-iso-nonyl phthalate (DINP) $\left(<0.01 \mathrm{mg} \mathrm{L}^{-1}\right)$, di-cyclohexyl phthalate (DCHP) (negligible solubility), di-n-octyl phthalate (DNOP) (water insoluble), and di-iso-decyl phthalate (DIDP) (water insoluble). Thus, DMP was chosen as a model compound for the remediation of contaminated aquatic water and the treatment of waste water.

The natural attenuation mechanisms which include chemical breakdown, biodegradation, and photolysis can decompose the PAEs [25]. The halftimes vary from days to years, depending on the environment especially the temperature and the properties of PAEs such as structure and length of functional groups. However, it takes a long time. Thus, many techniques have been used to treat the PAEs-containing water and waste, including physical treatments of adsorption $[32,33]$ and membrane processes such as ultrafiltration, nanofiltration, and reverse osmosis [34-38], biodegradation by microorganisms [25], and chemical processes of basecatalyzed hydrolysis, ultraviolet (UV) radiation, ozonation, combined UV radiation/ozonation, catalytic ozonation, and combined UV/catalytic ozonation [25, 26, 39, 40]. Among the above said methods, adsorption can effectively remove the PAEs from the solution with PAEs concentrated on the solid adsorbents. The adsorption has been also applied to other emerging contaminants $[41,42]$. The exhausted adsorbents are regenerated for reuse. The treatment of waste regeneration solution containing high-concentration PAEs is then followed. It is usually carried out by the destruction processes such as biological and chemical treatments noted above. Concerning the improvement of adsorption rate, proper surface area, and easy recovery of adsorbent, adsorption using novel magnetic micro-nano size magnetic adsorbents has been developed and employed for the removal of inorganic pollutants [43-46]. This study applied the micro size magnetic polyvinyl alcohol (M-PVAL) for the adsorption removal of organic DMP.

\section{Experimental}

2.1. Chemicals. The main chemicals used to synthesize the micro size adsorbents of magnetic polyvinyl alcohol MPVAL include the following: iron(III) chloride-6-hydrate $\left(\mathrm{FeCl}_{3} \cdot 6 \mathrm{H}_{2} \mathrm{O}\right.$, 99\%), iron(II) tetrahydrate $\left(\mathrm{FeCl}_{2} \cdot 4 \mathrm{H}_{2} \mathrm{O}\right.$, $99 \%)$, and ammonium hydroxide $\left(\mathrm{NH}_{3}, 25 \%\right)$ from Merck $\mathrm{KGaA}$ (Darmstadt, Germany), oleic acid $\left(\mathrm{CH}\left(\mathrm{CH}_{2}\right)_{7} \mathrm{COOH}\right.$, extra pure reagent) and polyvinyl alcohol $\left(\left(\mathrm{CHCH}_{2} \mathrm{OH}\right)_{n}\right.$, $99+\%)$ from Nacalai Tesque, Inc. (Kyoto, Japan), vinyl acetate $\left(\mathrm{CH}_{3} \mathrm{COOCHCH}_{2}, 99+\%\right)$ and divinyl benzene $\left(\mathrm{C}_{10} \mathrm{H}_{10}\right.$, $80 \%$ ) from Sigma-Aldrich, Inc. (Steinheim, Germany), benzoyl peroxide $\left(\mathrm{C}_{6} \mathrm{H}_{5} \mathrm{CO}, 99 \%\right.$, Jia Hwa Chemical, Co., Ltd., Taipei, Taiwan), and methylene blue (Loba Chemie Pvt. Ltd.,
Mumbai, India). The emerging contaminant of dimethyl phthalate DMP $\left(\mathrm{C}_{10} \mathrm{H}_{10} \mathrm{O}_{4}, 99.5 \%\right)$ was supplied by Hayashi Pure Chemical Industries Ltd. (Osaka, Japan).

\subsection{Methods and Analyses}

2.2.1. Preparation of Micro Size M-PVAL. Magnetic $\mathrm{Fe}_{3} \mathrm{O}_{4}$ (M) was prepared by chemical coprecipitation method. Ferrous chloride and ferric chloride were firstly dissolved using distilled water at $85^{\circ} \mathrm{C}$ in nitrogen environment. It followed the addition of aqueous ammonia to form the magnetic suspension of precipitated $\mathrm{Fe}_{3} \mathrm{O}_{4}$. Oleic acid acting as a dispersion agent was immediately and slowly fed into the suspension liquid until the appearance of clear supernatant liquid. This thus yielded the magnetite $M$. It was then synthesized to form magnetic polyvinyl acetate (M-PVAC) by suspension polymerization. For performing this, PVAL was dissolved via distilled water at $60^{\circ} \mathrm{C}$ in nitrogen environment to provide background solution for polymerization. After addition of magnetite $\mathrm{M}, \mathrm{VAC}$, and divinyl benzene, the suspension polymerization proceeded at $70^{\circ} \mathrm{C}$ for about $6 \mathrm{~h}$ and then cooled to $25^{\circ} \mathrm{C}$, forming M-PVAC. Washing with deionized water, its surface was modified by alcoholysis to produce a polymer adsorbent of magnetic polyvinyl alcohol M-PVAL. In alcoholysis, M-PVAC was suspended in methanol solution for $6 \mathrm{~h}$ to obtain M-PVAL. Detailed description of the above procedures can be found in Tseng et al. [45].

2.2.2. Isothermal Adsorption. DMP solutions with various concentrations were prepared. 0.1 g M-PVAL adsorbent was added into each $50 \mathrm{~mL}$ DMP solution filled in $125 \mathrm{~mL}$ flask. The initial $\mathrm{pH}$ value $\left(\mathrm{pH}_{0}\right)$ of solution was adjusted to desired value using $\mathrm{HCl}$ or $\mathrm{NaOH}$. The adsorptions with various initial DMP concentrations were conducted in a constant-bath shaker. A blank solution without M-PVAL adsorbent was tested along each batch of adsorptions.

After the adsorption of $8 \mathrm{~h}$, a magnet was attached beneath the flask to adhere the M-PVAL adsorbent. The $\mathrm{pH}$ value of solution was measured. The magnetic separated solution was withdrawn using syringe and filtered with $0.22 \mu \mathrm{m}$ filter. $2 \mathrm{~mL}$ filtrate was collected for the measurement of concentration.

2.2.3. Analyses. The magnetizations of $\mathrm{Fe}_{3} \mathrm{O}_{4}, \mathrm{M}-\mathrm{PVAC}$, and M-PVAL were measured by superconducting quantum interference device (SQUID) (model MPMS7, Quantum Design Inc., San Diego, CA). The Brunauer-Emmett-Teller (BET) surface area and particle size distribution of samples were determined by Perkin Elmer's Micromeritics ASAP 2000 (Perkin Elmer, Norcross, GA) and laser particle size analyzer (model LS 23 Fluid Module, Beckman Coulter Inc., Fullerton, CA), respectively. The surface structure and functional group of solids were analyzed using scanning electron microscope (SEM) (model JEOL-5610, JEOL Ltd., Tokyo, Japan) and Fourier-transform infrared spectrometer (FTIR) (model FTS-40, BIO-RAD Inc., Hercules, CA), respectively. A zeta potential meter (model Nano-Z, Malvern Inc., Worcestershire, UK) was employed to identify the zeta potentials of samples. The concentration of DMP was 


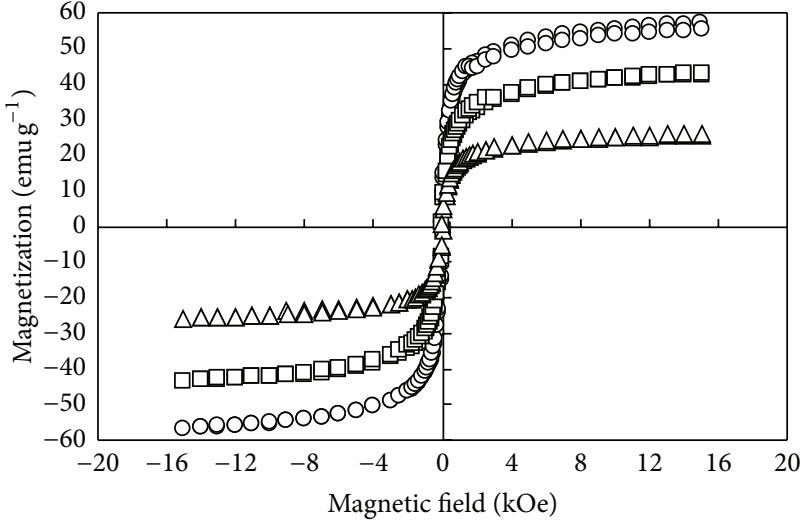

FIGURE 1: Magnetization curves of various magnetic particles. $\mathrm{O}, \square$, and $\triangle: \mathrm{Fe}_{3} \mathrm{O}_{4}$, PVAL: $\left[\mathrm{CH}_{2} \mathrm{CH}(\mathrm{OH})\right]_{n}$, and PVAC: $\left[\mathrm{CH}_{2} \mathrm{CH}\left(\mathrm{OCOCH}_{3}\right)\right]_{n}$.

measured using UV-spectrophotometer (model UV mini1240, Shimazu, Kyoto, Japan).

\section{Results and Discussion}

3.1. Characteristics of Micro Size M-PVAL. Figure 1 illustrates the magnetization versus magnetic field of $\mathrm{Fe}_{3} \mathrm{O}_{4}, \mathrm{M}-\mathrm{PVAC}$, and M-PVAL. All three particles exhibit magnetization at the presence of magnetic field while they possess no magnetization in the absence of externally applied magnetic field, showing the unique characteristics of superparamagnetism. This property offers the advantages for using the fresh solid adsorbent to adsorb the solute species in the absence of magnetic field and for removing the exhausted adsorbent from solution by magnetic separation for subsequent regeneration. The saturation magnetizations of $\mathrm{Fe}_{3} \mathrm{O}_{4}, \mathrm{M}-\mathrm{PVAC}$, and M-PVAL are 57.2, 26.0, and $43.2 \mathrm{emu} \mathrm{g}^{-1}$, respectively. The saturation magnetizations of $\mathrm{Fe}_{3} \mathrm{O}_{4}$ and M-PVAC are close to those of Chang et al. [43] of $56.45 \mathrm{emu} \mathrm{g}^{-1}$ and of Tseng et al. [45] of $25 \mathrm{emu} \mathrm{g}^{-1}$, respectively. The reduction of saturation magnetizations of M-PVAC and M-PVAL compared to that of $\mathrm{Fe}_{3} \mathrm{O}_{4}$ with relative magnitudes of $45.45 \%$ and $75.52 \%$, respectively, is due to the coating of polymer matter onto $\mathrm{Fe}_{3} \mathrm{O}_{4}$. The functional group of $-\mathrm{OCOCH}_{3}$ of $\mathrm{M}$-PVAC is modified to -OH of M-PVAL, resulting in less organics contained in $\mathrm{M}$ PVAL. Thus, for the same amount of magnetic adsorbent, the content of $\mathrm{Fe}_{3} \mathrm{O}_{4}$ in M-PVAL is higher than that in M-PVAC, possessing a comparatively higher saturation magnetization.

The success of synthesis of M-PVAL with functional group of -OH can be further justified by the peak of adsorption (inverse of transmittance) at $3400 \mathrm{~cm}^{-1}$ in FTIR diagram presented in Figure 2. The peak at $1266 \mathrm{~cm}^{-1}$ also reveals the binding of $\mathrm{C}-\mathrm{O}$. The same characteristics of nonmagnetic polyvinyl alcohol were also reported by Kaczmarek et al. [47] and Majumdar and Adhikari [48].

Figure 3 depicts the particle size distribution of M-PVAL in terms of number. The number mean diameter $\left(d_{\mathrm{PNA}}\right)$ and number median diameter $\left(d_{\mathrm{PNM}}\right)$ are 0.75 and $0.589 \mu \mathrm{m}$,

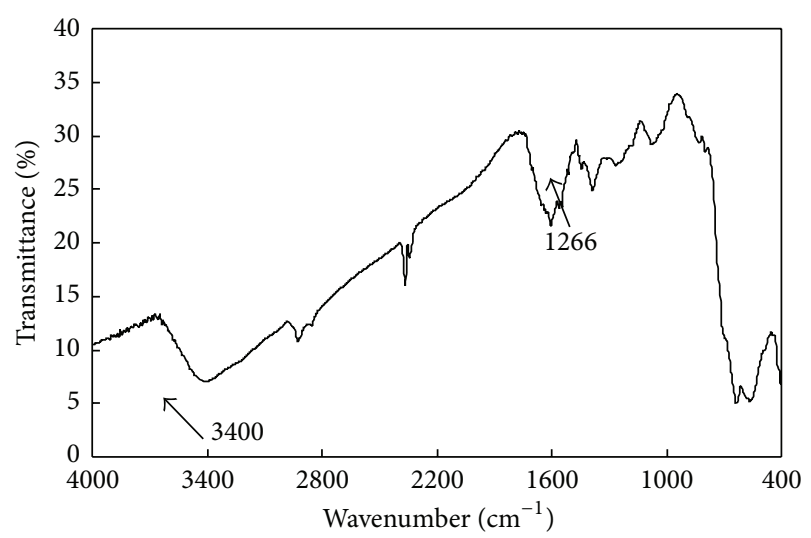

FIgURE 2: FTIR diagram of M-PVAL.

TABLE 1: Some major physical characteristics of M-PVAL.

\begin{tabular}{|c|c|c|}
\hline & & $\begin{array}{l}\text { Adsorbent: } \\
\text { M-PVAL }\end{array}$ \\
\hline \multirow{3}{*}{$\begin{array}{l}\text { Density } \\
\text { analysis }\end{array}$} & Bulk density, $\rho_{P}\left(\mathrm{~g} \mathrm{~cm}^{-3}\right)$ & 2.40 \\
\hline & True density, $\rho_{S}\left(\mathrm{~g} \mathrm{~cm}^{-3}\right)$ & 2.49 \\
\hline & Particle porosity, $\varepsilon_{P}{ }^{\mathrm{a}}$ & 0.03 \\
\hline \multirow{2}{*}{$\begin{array}{l}\text { Surface } \\
\text { area }^{b, c}\end{array}$} & $\begin{array}{c}\text { Surface area by BET } \\
\text { analysis }\left(A_{B}\right) \\
\left(\mathrm{m}^{2} \mathrm{~g}^{-1}\right)\end{array}$ & 73.1 \\
\hline & $\begin{array}{c}\text { Constant of BET } \\
\text { equation }\left(K_{B}\right) \\
(-)\end{array}$ & 63 \\
\hline $\begin{array}{l}\text { Particle } \\
\text { diameter }^{\mathrm{d}} \\
(\mu \mathrm{m})\end{array}$ & $\begin{array}{c}\text { Average particle } \\
\text { diameter by number }\end{array}$ & 0.75 \\
\hline
\end{tabular}

${ }^{\mathrm{a} C a l c u l a t e d}$ using $1-\left(\rho_{P} / \rho_{S}\right)$.

${ }^{\mathrm{b}}$ BET surface area was analyzed using ASAP2000, Micromeritics.

${ }^{\mathrm{c}}$ Surface area estimated using Langmuir equation $\left(A_{\mathrm{L}}\right)$ is about $102.42 \mathrm{~m}^{2} \mathrm{~g}^{-1}$.

${ }^{\mathrm{d}}$ Analyzed using LS 23 Fluid Module, Beckman Coulter.

respectively. Most of the M-PVAL particles have size less than $1 \mu \mathrm{m}$.

The major physical characteristics of M-PVAL are summarized in Table 1 . The particle porosity $\varepsilon_{P}$ is 0.03 , indicating the micro size M-PVAL is essentially nonporous. This ensures that the pore diffusion is negligible in adsorption process.

3.2. Isothermal Adsorption of DMP. Langmuir, Freundlich, and $\mathrm{D}-\mathrm{R}$ isotherms were tested to examine the adsorptions of DMP on M-PVAL for three cases, namely, Cases 1 and 3 with initial $\mathrm{pH}_{0}$ adjusted at 5 and 7 and Case 2 without adjustment of $\mathrm{pH}_{0}$ with $\mathrm{pH}$ value in 6.04-6.64, respectively. At equilibrium, the $\mathrm{pH}$ values for the three cases with $\mathrm{pH}_{0}=$ $5,6.04-6.64$, and 7 increase to about 7.36-7.87, 6.9-8.05, and $7.42-8.39$, respectively. This is consistent with the adsorption of slightly acidic DMP by base M-PVAL, which exhibits $\mathrm{pH}$ of 9.1 and zeta potential of $-35.6 \mathrm{mv}$ when dispersed in deionized (DI) water as illustrated in Figure 4. The values of 
TABLE 2: Values of isotherm parameters and correlation coefficients $\left(r^{2}\right)^{\mathrm{a}}$ with different initial $\mathrm{pH}$ values.

\begin{tabular}{|c|c|c|c|c|c|c|c|c|c|c|}
\hline \multirow{2}{*}{$\mathrm{pH}_{0}{ }^{\mathrm{b}}$} & \multicolumn{3}{|c|}{ Langmuir isotherm } & \multicolumn{3}{|c|}{ Freundlich isotherm } & \multicolumn{4}{|c|}{ Dubinin-Radushkevich isotherm } \\
\hline & $q_{\mathrm{L}}\left(\mathrm{mgg} \mathrm{g}^{-1}\right)$ & $K_{\mathrm{L}}\left(\mathrm{m}^{3} \mathrm{~g}^{-1}\right)$ & $r_{\mathrm{L}}^{2}$ & $k_{\mathrm{F}}\left(\left(\mathrm{mg} \mathrm{g}^{-1}\right)\left(\mathrm{g} \mathrm{m}^{-3}\right)^{-1 / n \mathrm{~F}}\right)$ & $n_{\mathrm{F}}$ & $r_{\mathrm{F}}^{2}$ & $B_{\mathrm{D}}\left(\mathrm{mol}^{2} \mathrm{~J}^{-2}\right)$ & $E_{\mathrm{D}}\left(\mathrm{kJ} \mathrm{mol}^{-1}\right)$ & $q_{m \mathrm{D}}\left(\mathrm{mgg}^{-1}\right)$ & $r_{\mathrm{D}}{ }^{2}$ \\
\hline $5^{\mathrm{c}}$ & 4.01 & 0.12 & 0.97 & 0.80 & 2.59 & 0.92 & $1.00 \times 10^{-8}$ & 7.04 & 3.8 & 0.91 \\
\hline $6.04-6.64^{\mathrm{c}}$ & 5.21 & 0.056 & 0.94 & 0.60 & 2.19 & 0.97 & $1.19 \times 10^{-8}$ & 6.48 & 3.84 & 0.90 \\
\hline $7^{\mathrm{c}}$ & 4.22 & 0.15 & 0.95 & 0.95 & 2.59 & 0.81 & $0.96 \times 10^{-8}$ & 7.19 & 4.32 & 0.85 \\
\hline
\end{tabular}

${ }^{\mathrm{a}} r_{\mathrm{L}}{ }^{2}, r_{\mathrm{F}}{ }^{2}$, and $r_{\mathrm{D}}{ }^{2}$ are correlation coefficients by means of fitting the experimental data to Langmuir, Freundlich, and Dubinin-Radushkevich isotherms, respectively.

${ }^{\mathrm{b}}$ The ranges of the equilibrium concentrations of the experiments performed are 0.61-92.9, 0.82-91.1, and 0.52-91.3 $\mathrm{mg} \mathrm{L}^{-1}$ for $\mathrm{pH}_{0}$ of 5, 6.04-6.64, and 7, respectively.

${ }^{{ }^{c}}$ The final $\mathrm{pH}$ values of solutions at the end of experiments were about 7.36-7.87, 6.9-8.05, and 7.42-8.39 for $\mathrm{pH}_{0}=5,6.04-6.64$, and 7, respectively.

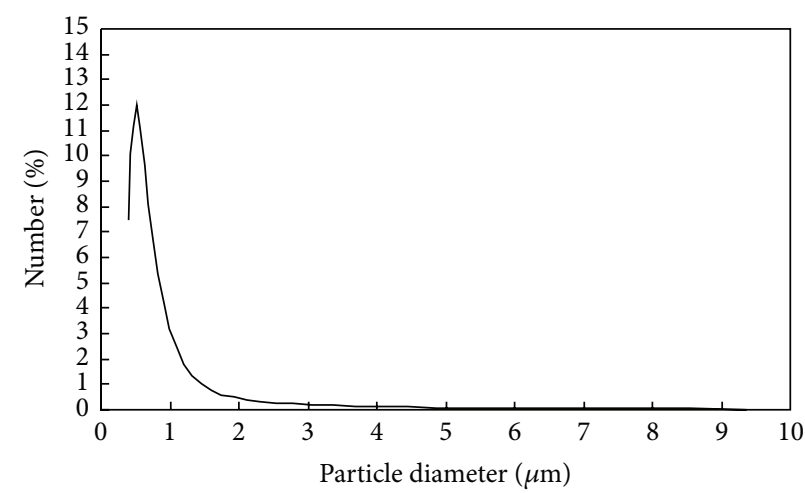

(a)

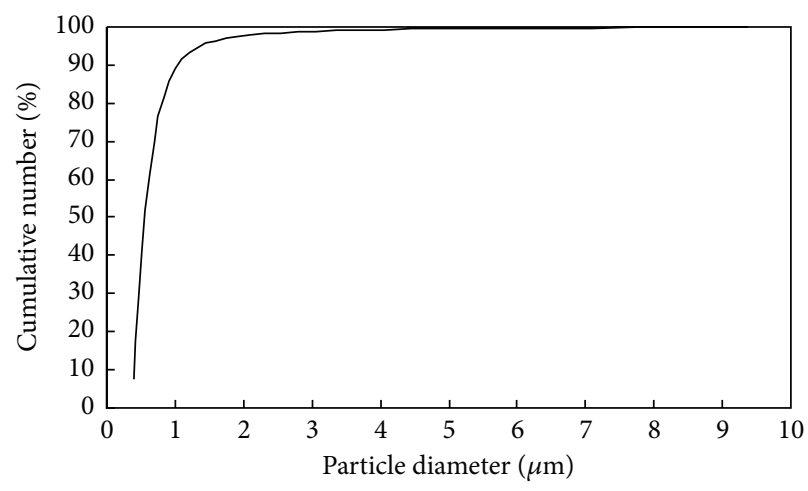

(b)

FIgURE 3: The relationship between (a) differential number $\%$ of M-PVAL and $d_{P}$ and (b) cumulative number $\%$ and $d_{P}$.

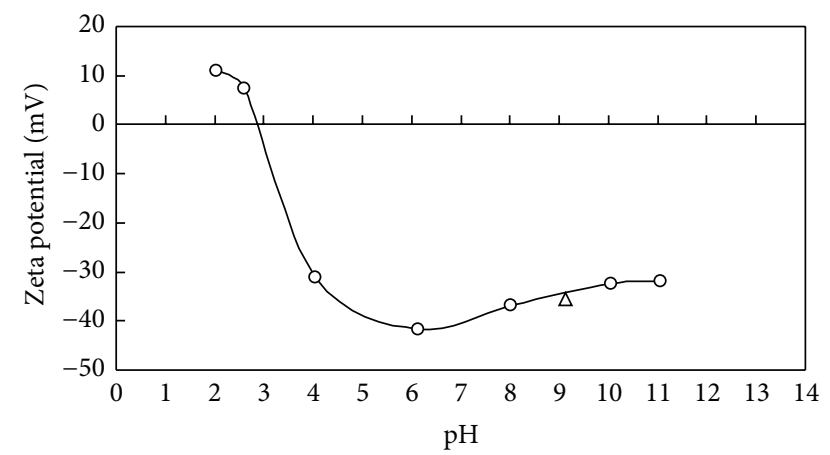

FIgURE 4: Zeta potentials of M-PVAL at various $\mathrm{pH}$ values. $\bigcirc$ and $\triangle: \mathrm{pH}$ values of aqueous solutions containing M-PVAL are (1) controlled with addition of $\mathrm{HCl}$ or $\mathrm{NaOH}$ and (2) not controlled.

isotherm parameters of corresponding isotherms are listed in Table 2.

The Langmuir isotherm deduces the values of unimolecular layer $q_{\mathrm{L}}$ of $4.01,5.21$, and $4.22 \mathrm{~g} \mathrm{~kg}^{-1}$ for Cases 1,2 , and 3 , respectively, indicating minor effect of adjustment of $\mathrm{pH}_{0}$ on the saturation capacity $q_{\mathrm{L}}$ with Case 2 without adjustment of $\mathrm{pH}_{0}$ yielding higher value. The adsorption equilibrium constants $K_{\mathrm{L}}$ exhibit difference with Cases 1 and 2 with adjustment of $\mathrm{pH}_{0}$ giving higher values. The cause might be due to the effects of adjustment addition of $\mathrm{HCl}$ or $\mathrm{NaOH}$ on the adsorption. The balance of decrease of $q_{\mathrm{L}}$ while increase of $K_{\mathrm{L}}$ by the adjustment of $\mathrm{pH}_{0}$ results in the close adsorption behaviors for the three cases as depicted in Figures 5, 6, and 7. The $r$-squares of model fittings as shown in Figure 8 are greater than 0.94 , indicating good agreement. The results thus suggest performing the adsorption without adjustment of $\mathrm{pH}_{0}$.

The heterogeneity factors $n_{\mathrm{F}}$ of Freundlich isotherm obtained for the three cases are 2.59, 2.19, and 2.59, respectively. All these values are greater than 1 , revealing that the adsorption of the noted DMP/M-PVAL systems is favorable. The $k_{\mathrm{F}}$ values are about $0.6-0.95\left(\mathrm{mg} \mathrm{g}^{-1}\right)\left(\mathrm{g} \mathrm{m}^{-3}\right)^{-1 / n_{\mathrm{F}}}$. The fittings of Freundlich isotherm as illustrated in Figure 9 are fairly satisfactory with $r$-square higher than 0.81 , which, however, is not as good as those of Langmuir isotherm. The good fitting of Langmuir isotherm for the adsorbent M-PVAL may be further justified by noting that the M-PVAL is tiny with number average particle size of $0.75 \mu \mathrm{m}$ which exhibits fast adsorption rate with low diffusion resistance thus in favor of the formation of thin monolayer.

Applying D-R isotherm for the three cases gives the saturation adsorption capacity $q_{m \mathrm{D}}$ of $3.8,3.84$, and $4.32 \mathrm{~g} \mathrm{~kg}^{-1}$, respectively. The values are comparable to those of $q_{\mathrm{L}}$ of 4.01 , 5.21 , and $4.22 \mathrm{~g} \mathrm{~kg}^{-1}$ adopting Langmuir isotherm, further supporting the validity of Langmuir isotherm. The adsorption activation energies per mole of D-R isotherm $E_{\mathrm{D}}$ are 7.04, 6.48 , and $7.19 \mathrm{~kJ} \mathrm{~mol}^{-1}$, respectively. The $r$-squares of fittings of D-R isotherm presented in Figure 10 are higher than 0.85 , showing fair agreement. The obtained values of $E_{\mathrm{D}}$ of $6.48-$ $7.19 \mathrm{~kJ} \mathrm{~mol}^{-1}$ are lower than those of $8-16 \mathrm{~kJ} \mathrm{~mol}^{-1}$ reported 


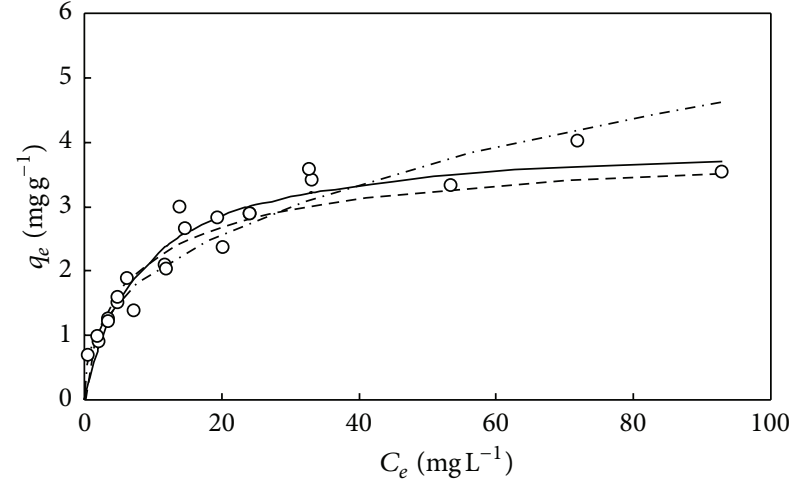

FIgURE 5: The simulations of Langmuir isotherm (-), Freundlich isotherm (- - ), and D-R isotherm (---) for adsorption of DMP on M-PVAL with $\mathrm{pH}_{0}=5$. Final $\mathrm{pH}=7.36-7.87$. $\mathrm{O}$ : experimental data.

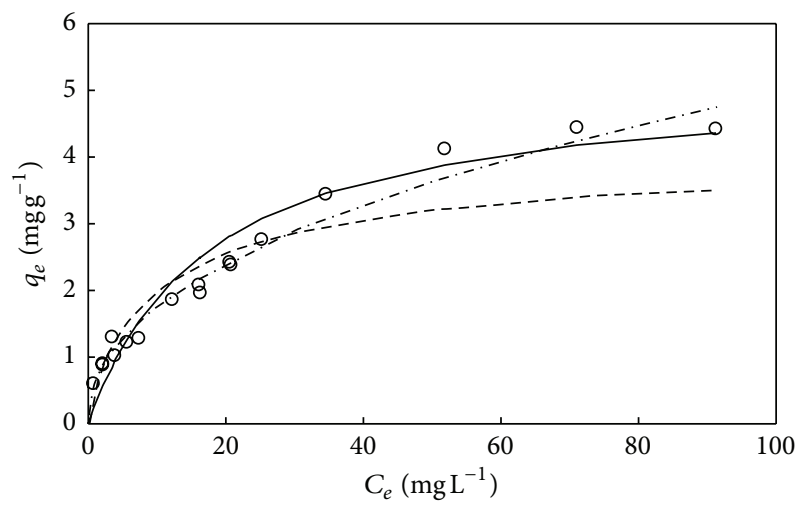

FIGURE 6: The simulations of Langmuir isotherm (-), Freundlich isotherm (---), and D-R isotherm (---) for adsorption of DMP on MPVAL. $\mathrm{pH}_{0}=6.04-6.64$. Final $\mathrm{pH}=6.9-8.05$. O: experimental data.

by Özcan et al. for the adsorption of ion-exchange form [49]. The low values of $E_{\mathrm{D}}$ thus support that the adsorption process of DMP/M-PVAL in this study proceeds naturally.

The above results indicate that the equilibrium of DMP/ M-PVAL exhibits saturation value. Further, among the three isotherms examined, the Langmuir isotherm shows the best agreement and thus is more appropriate to describe the adsorption equilibrium of DMP/M-PVAL system.

\section{Conclusions}

Some major conclusions may be drawn from the adsorption removal of DMP using superparamagnetic micro size adsorbent of M-PVAL examined in this study as follows:

(1) $\mathrm{Fe}_{3} \mathrm{O}_{4}$, M-PVAC, and M-PVAL solid particles prepared possess superparamagnetism with saturation magnetizations of $57.2,26.0$, and $43.2 \mathrm{emu} \mathrm{g}^{-1}$, respectively. The magnetic particle with more organic adsorbent content has lower magnetization.

(2) The M-PVAL can adsorb the DMP under the condition without externally applied magnetic field, while the exhausted saturated M-PVAL can be magnetically

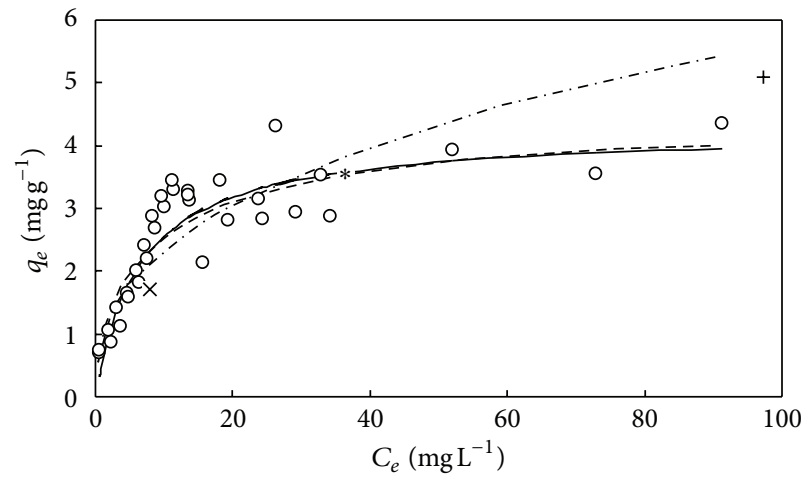

FIgURE 7: The simulations of Langmuir isotherm (-), Freundlich isotherm (- - ), and D-R isotherm (---) for adsorption of DMP on M-PVAL with $\mathrm{pH}_{0}=7$. Final $\mathrm{pH}=7.42-8.39$. $\bigcirc$ : experimental data. $\times, *$, and $+: q_{e}$ versus $C_{e}$ with $C_{0}=9.55,40.0$, and $102.4 \mathrm{mg} \mathrm{L}^{-1}$.

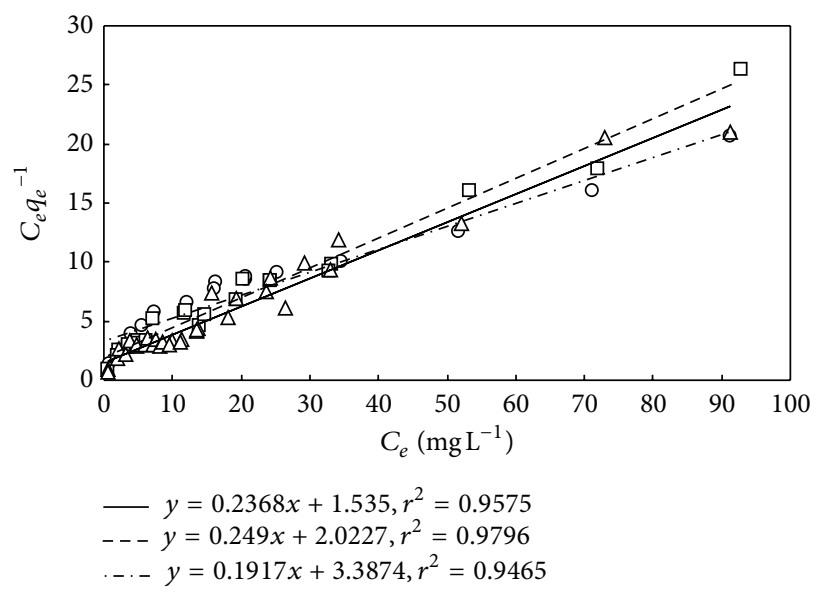

FIgURE 8: Adsorption of DMP on M-PVAL employing Langmuir isotherm. Cases with $\mathrm{pH}_{0}=5,6.04-6.64$, and 7 are expressed as $\square$ $(--): y=0.249 x+2.20227, \bigcirc(-\cdot-): y=0.1917 x+3.3874$, and $\triangle$ $(-): y=0.2368 x+1.535$.

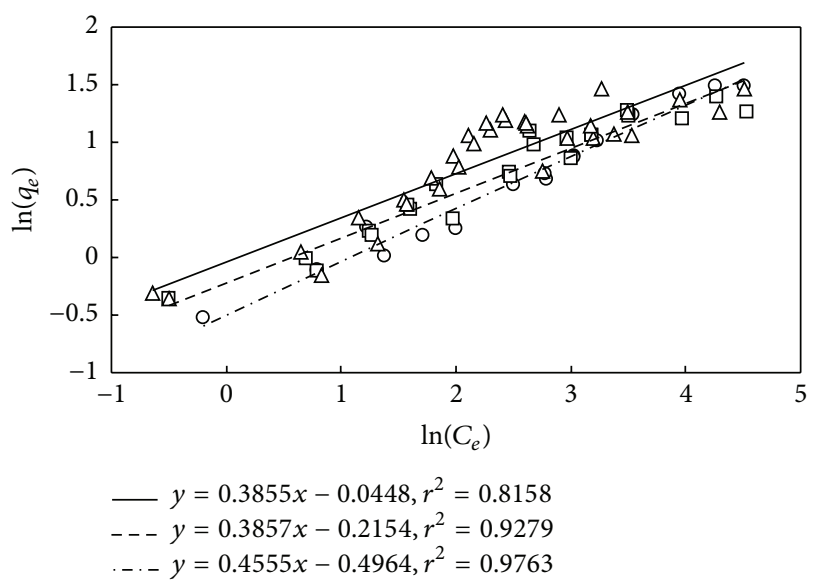

FIgURE 9: Adsorption of DMP on M-PVAL employing Freundlich isotherm. Cases with $\mathrm{pH}_{0}=5,6.04-6.64$, and 7 are expressed as $\square$ $(--): y=0.3857 x-0.2145, \bigcirc(-\cdot): y=0.4555 x-0.4964$, and $\triangle$ $(-): y=0.3855 x-0.0448$. 


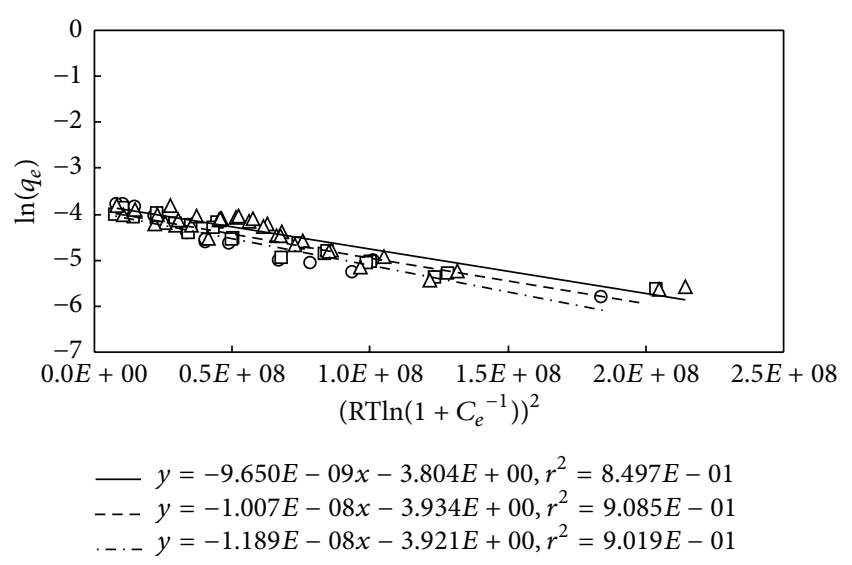

Figure 10: Adsorption of DMP on M-PVAL employing DubininRadushkevich isotherm. Cases with $\mathrm{pH}_{0}=5,6.04-6.64$, and 7 are expressed as $\square(--): y=-1.007 E-08 x-3.934, \bigcirc(-\cdot-): y=-1.189 E-$ $08 x-3.921$, and $\triangle(-): y=-9.950 E-09 x-3.804$.

separated from the treated liquid for the regeneration by applying externally magnetic field.

(3) Langmuir, Freundlich, and Dubinin-Radushkevich $(\mathrm{D}-\mathrm{R})$ isotherms were tested to describe the equilibrium of DMP/M-PVAL for three cases: (1) adjusting initial $\mathrm{pH}\left(\mathrm{pH}_{0}\right)$ at 5 , (2) no adjustment of $\mathrm{pH}$ with $\mathrm{pH}_{0}=6.04-6.64$, and (3) adjustment of $\mathrm{pH}_{0}$ at 7, indicating that Langmuir isotherm offers the best fitting with good agreement.

(4) The unimolecular layer $q_{\mathrm{L}}$ of Langmuir isotherm is 4.01, 5.21, and $4.22 \mathrm{mg} \mathrm{g}^{-1}$, respectively, for the three cases examined, suggesting no adjustment of $\mathrm{pH}_{0}$ for practical application.

(5) For the three cases investigated, the adoption of Freundlich isotherm gives heterogeneity factor $n_{\mathrm{F}}$ of 2.59 , 2.19 , and 2.59, respectively, indicating that the said adsorption is favorable with $n_{\mathrm{F}}$ greater than 1 .

(6) The adsorption activation energies per mole $E_{\mathrm{D}}$ of D$\mathrm{R}$ isotherm deduced are, respectively, of low values of $7.04,6.48$, and $7.19 \mathrm{~kJ} \mathrm{~mol}^{-1}$ for the three cases studied, supporting the natural occurrence of the adsorption of DMP/M-PVAL system.

\section{Abbreviations}

$A_{B}$ : Surface area by BET analysis $\left(\mathrm{m}^{2} \mathrm{~g}^{-1}\right)$

$A_{\mathrm{L}}:$ Surface area estimated using Langmuir eq. $\left(\mathrm{m}^{2} \mathrm{~g}^{-1}\right)$

$B_{\mathrm{D}}: \quad \mathrm{D}-\mathrm{R}$ isotherm constant $\left(\mathrm{mol}^{2} \mathrm{~J}^{-2}\right)$

BBP: Benzyl butyl phthalate

BET: Brunauer-Emmett-Teller

C: $\quad$ Adsorbate concentration in the liquid phase $\left(\mathrm{g} \mathrm{m}^{-3}\right.$ or $\left.\mathrm{mmol} \mathrm{L}^{-1}\right)$

$C_{e}$ : Adsorbate concentration in the liquid phase at equilibrium $\left(\mathrm{g} \mathrm{m}^{-3}\right.$ or $\mathrm{mmol} \mathrm{L}^{-1}$ )
D-R:

$\mathrm{D}-\mathrm{R}$ isotherm:

DBP:

DCHP:

DEHP:

DEP:

DHP:

DIDP:

DINP:

DMP:

DNOP:

$d_{P}$ :

$d_{\mathrm{PNA}}:$

$d_{\mathrm{PNM}}$ :

$E_{\mathrm{D}}$ :

$E_{P}:$

ECs:

FTIR:

Freundlich isotherm: $q_{e}=k_{\mathrm{F}} C^{1 / n_{\mathrm{F}}}$

$K_{B}$ :

$K_{\mathrm{L}}$ :

$k_{\mathrm{F}}:$

Langmuir isotherm:

M:

M-PVAC:

M-PVAL:

$n_{\mathrm{F}}:$

PAEs:

PE:

PP:

PS:

PVC:

$\mathrm{pH}_{0}$ :

$q$ :

$q_{e}:$

$q_{\mathrm{L}}:$

$q_{m \mathrm{D}}:$

$R:$

$r_{\mathrm{L}}^{2}, r_{\mathrm{F}}^{2}$, and $r_{\mathrm{D}}^{2}$ : $=1 /\left(2 B_{\mathrm{D}}\right)^{0.5}$ esters

Polystyrene $\mathrm{mmolg}^{-1}$ )
Dubinin-Radushkevich

$q_{e}=q_{m \mathrm{D}} \exp \left(-B_{\mathrm{D}} E_{P}^{2}\right)$

Di-n-butyl phthalate

Di-cyclohexyl phthalate

Di-(2-ethyl hexyl) phthalate

Di-ethyl phthalate

Di-hexyl phthalate

Di-iso-decyl phthalate

Di-iso-nonyl phthalate

Dimethyl phthalate

Di-n-octyl phthalate

Particle diameter

Number mean diameter

Number median diameter

Adsorption activation energy per mole of D-R isotherm $\left(\mathrm{kJ} \mathrm{mol}^{-1}\right)$,

Polanyi potential $\left(\mathrm{J} \mathrm{mol}^{-1}\right)$,

$=R T \ln \left(1+C_{e}^{-1}\right)$

Emerging contaminants

Fourier-transform infrared

spectrometer

$q_{e}=k_{\mathrm{F}} C_{e}$
Constant of BET equation (-)

Equilibrium constant of Langmuir isotherm $\left(\mathrm{m}^{3} \mathrm{~g}^{-1}\right)$

Constant of Freundlich isotherm

$\left(\left(\mathrm{mg} \mathrm{g}^{-1}\right)\left(\mathrm{g} \mathrm{m}^{-3}\right)^{-1 / n_{\mathrm{F}}}\right)$

$q_{e}=q_{\mathrm{L}} K_{\mathrm{L}} C_{e} /\left(1+K_{\mathrm{L}} C_{e}\right)$

Magnetic $\mathrm{Fe}_{3} \mathrm{O}_{4}$

Magnetic polyvinyl acetate

Magnetic polyvinyl alcohol

Heterogeneity factor of Freundlich isotherm (-)

Phthalate acid esters or phthalate

Polyethylene

Polypropylene

Polyvinyl chloride

Initial $\mathrm{pH}$ value

Adsorbate concentration in solid phase $\left(\mathrm{mg} \mathrm{g}^{-1}\right.$ or $\mathrm{g} \mathrm{kg}^{-1}$ or

Adsorbate concentration in solid phase at equilibrium $\left(\mathrm{mg} \mathrm{g}^{-1}\right.$ or $\mathrm{g} \mathrm{kg}^{-1}$ or $\mathrm{mmol} \mathrm{g}^{-1}$ )

Unimolecular layer of Langmuir isotherm $\left(\mathrm{mg} \mathrm{g}^{-1}\right.$ or $\left.\mathrm{g} \mathrm{kg}^{-1}\right)$

$\mathrm{D}-\mathrm{R}$ isotherm constant denoting saturation adsorption capacity

$\left(\mathrm{mgg}^{-1}\right.$ or $\left.\mathrm{mmolg}^{-1}\right)$

Universal gas constant

$\left(8.314 \mathrm{~J} \mathrm{~mol}^{-1} \mathrm{~K}^{-1}\right.$ )

Correlation coefficients by means of fitting the experimental data to Langmuir, Freundlich, and D-R isotherms, respectively 
SEM: Scanning electron microscope

SQUID: Superconducting quantum interference device

$T: \quad$ Absolute temperature (K)

UV: Ultraviolet.

Greek

$\varepsilon_{P}$ : Adsorbent porosity

$\rho_{P}$ : Apparent particle density $\left(\mathrm{kg} \mathrm{m}^{-3}\right)$

$\rho_{s}$ : True particle density $\left(\mathrm{kg} \mathrm{m}^{-3}\right)$

$\rho_{w}$ : Density of water $\left(\mathrm{kg} \mathrm{m}^{-3}\right)$.

\section{Conflict of Interests}

The authors declare that there is no conflict of interests regarding the publication of this paper.

\section{Acknowledgment}

The authors are grateful for the financial support from Ministry of Science and Technology (formerly the National Science Council) of Taiwan.

\section{References}

[1] A. Z. Aris, A. S. Shamsuddin, and S. M. Praveena, "Occurrence of $17 \alpha$-ethynylestradiol (EE2) in the environment and effect on exposed biota: a review," Environment International, vol. 69, pp. 104-119, 2014.

[2] S. Bartelt-Hunt, D. D. Snow, T. Damon-Powell, and D. Miesbach, "Occurrence of steroid hormones and antibiotics in shallow groundwater impacted by livestock waste control facilities," Journal of Contaminant Hydrology, vol. 123, no. 3-4, pp. 94-103, 2011.

[3] J.-P. Besse and J. Garric, "Progestagens for human use, exposure and hazard assessment for the aquatic environment," Environmental Pollution, vol. 157, no. 12, pp. 3485-3494, 2009.

[4] M. Bodzek and M. Dudziak, "Estrogenic micropollutants in the aqueous environment: sources, dispersion and removal," in Proceedings of the 2nd National Congress of Environmental Engineering, pp. 213-220, September 2005.

[5] C.-H. Chen, P.-H. Chou, M. Kawanishi, and T. Yagi, "Occurrence of xenobiotic ligands for retinoid $\mathrm{X}$ receptors and thyroid hormone receptors in the aquatic environment of Taiwan," Marine Pollution Bulletin, vol. 85, no. 2, pp. 613-618, 2014.

[6] M. Gorga, S. Insa, M. Petrovic, and D. Barceló, "Occurrence and spatial distribution of EDCs and related compounds in waters and sediments of Iberian rivers," Science of the Total Environment, vol. 503-504, pp. 69-86, 2015.

[7] M. Ihara, M. O. Ihara, V. Kumar et al., "Co-occurrence of estrogenic and antiestrogenic activities in wastewater: quantitative evaluation of balance by in vitro ER $\alpha$ reporter gene assay and chemical analysis," Environmental Science and Technology, vol. 48, no. 11, pp. 6366-6373, 2014.

[8] M. Kuster, M. José López de Alda, and D. Barceló, "Analysis and distribution of estrogens and progestogens in sewage sludge, soils and sediments," TrAC-Trends in Analytical Chemistry, vol. 23, no. 10-11, pp. 790-798, 2004.
[9] W. C. Li, "Occurrence, sources, and fate of pharmaceuticals in aquatic environment and soil," Environmental Pollution, vol. 187, pp. 193-201, 2014.

[10] X. Li, W. Zheng, and W. R. Kelly, "Occurrence and removal of pharmaceutical and hormone contaminants in rural wastewater treatment lagoons," Science of the Total Environment, vol. 445446, pp. 22-28, 2013.

[11] M. Long, J. Strand, P. Lassen et al., "Endocrine-disrupting effects of compounds in Danish streams," Archives of Environmental Contamination and Toxicology, vol. 66, no. 1, pp. 1-18, 2014.

[12] T. Manickum and W. John, "Occurrence, fate and environmental risk assessment of endocrine disrupting compounds at the wastewater treatment works in Pietermaritzburg (South Africa)," Science of the Total Environment, vol. 468-469, pp. 584597, 2014.

[13] A. Pal, K. Y.-H. Gin, A. Y.-C. Lin, and M. Reinhard, "Impacts of emerging organic contaminants on freshwater resources: review of recent occurrences, sources, fate and effects," Science of the Total Environment, vol. 408, no. 24, pp. 6062-6069, 2010.

[14] A. Sengupta, J. M. Lyons, D. J. Smith et al., "The occurrence and fate of chemicals of emerging concern in coastal urban rivers receiving discharge of treated municipal wastewater effluent," Environmental Toxicology and Chemistry, vol. 33, no. 2, pp. 350358, 2014.

[15] H. T. Thanh Thuy and T. D. Nguyen, "The potential environmental risks of pharmaceuticals in Vietnamese aquatic systems: case study of antibiotics and synthetic hormones," Environmental Science and Pollution Research, vol. 20, no. 11, pp. 8132-8140, 2013.

[16] Y. Xu, F. Luo, A. Pal, K. Y.-H. Gin, and M. Reinhard, "Occurrence of emerging organic contaminants in a tropical urban catchment in Singapore," Chemosphere, vol. 83, no. 7, pp. 963969, 2011.

[17] S. Froehner, K. S. Machado, E. Stefan, T. Bleninger, E. C. da Rosa, and C. D. C. Martins, "Occurrence of selected estrogens in mangrove sediments," Marine Pollution Bulletin, vol. 64, no. 1, pp. 75-79, 2012.

[18] H. Liu, H. Liang, Y. Liang et al., "Distribution of phthalate esters in alluvial sediment: a case study at JiangHan Plain, Central China," Chemosphere, vol. 78, no. 4, pp. 382-388, 2010.

[19] Y. B. Ho, M. P. Zakaria, P. A. Latif, and N. Saari, "Occurrence of veterinary antibiotics and progesterone in broiler manure and agricultural soil in Malaysia," Science of the Total Environment, vol. 488-489, no. 1, pp. 261-267, 2014.

[20] P. Q. Fu, K. Kawamura, C. M. Pavuluri, T. Swaminathan, and J. Chen, "Molecular characterization of urban organic aerosol in tropical India: contributions of primary emissions and secondary photooxidation," Atmospheric Chemistry and Physics, vol. 10, no. 6, pp. 2663-2689, 2010.

[21] M. Wormuth, M. Scheringer, M. Vollenweider, and K. Hungerbühler, "What are the sources of exposure to eight frequently used phthalic acid esters in Europeans?" Risk Analysis, vol. 26, no. 3, pp. 803-824, 2006.

[22] D. D. Snow, D. A. Cassada, S. L. Bartelt-Hunt et al., "Detection, occurrence and fate of emerging contaminants in agricultural environments," Water Environment Research, vol. 84, no. 10, pp. 764-785, 2012.

[23] W. A. Stirk and J. van Staden, "Plant growth regulators in seaweeds: occurrence, regulation and functions," Advances in Botanical Research, vol. 71, pp. 125-159, 2014. 
[24] B. J. Danzo, "The effects of environmental hormones on reproduction," Cellular and Molecular Life Sciences, vol. 54, no. 11, pp. 1249-1264, 1998.

[25] M. J. Bauer, R. Herrmann, A. Martin, and H. Zellmann, "Chemodynamics, transport behaviour and treatment of phthalic acid esters in municipal landfill leachates," Water Science and Technology, vol. 38, no. 2, pp. 185-192, 1998.

[26] C.-C. Chang, C.-Y. Chiu, C.-Y. Chang et al., "Combined photolysis and catalytic ozonation of dimethyl phthalate in a highgravity rotating packed bed," Journal of Hazardous Materials, vol. 161, no. 1, pp. 287-293, 2009.

[27] C. S. Liao, P. F. Chang, and S. Y. Yuan, "Environmental hormones: environmental distribution of plastics additives of phthalate esters," Bi-Monthly Journal of Environmental Analysis, no. 38, pp. 12-16, 2001 (Chinese).

[28] C. A. Staples, D. R. Peterson, T. F. Parkerton, and W. J. Adams, "The environmental fate of phthalate esters: a literature review," Chemosphere, vol. 35, no. 4, pp. 667-749, 1997.

[29] A. Turner and M. C. Rawling, "The behaviour of di-(2-ethylhexyl) phthalate in estuaries," Marine Chemistry, vol. 68 , no. 3 , pp. 203-217, 2000.

[30] M. Vitali, M. Guidotti, G. Macilenti, and C. Cremisini, "Phthalate esters in freshwaters as markers of contamination sourcesa site study in Italy," Environment International, vol. 23, no. 3, pp. 337-347, 1997.

[31] J. T. Baker, Material Safety Data Sheets (MSDS): Dimethyl Phthalate, D6936, Mallinckrodt Baker, 1996.

[32] E. Ayranci and E. Bayram, "Adsorption of phthalic acid and its esters onto high-area activated carbon-cloth studied by in situ UV-spectroscopy," Journal of Hazardous Materials, vol. 122, no. 1-2, pp. 147-153, 2005.

[33] W. Den, H. C. Liu, S. F. Chan, K. T. Kin, and C. Huang, "Adsorption of phthalate esters with multiwalled carbon nanotubes and its application," Journal of Environmental Engineering and Management, vol. 16, no. 4, pp. 275-282, 2006.

[34] D. Jermann, W. Pronk, M. Boller, and A. I. Schäfer, “The role of NOM fouling for the retention of estradiol and ibuprofen during ultrafiltration," Journal of Membrane Science, vol. 329, no. 1-2, pp. 75-84, 2009.

[35] Y. Luo, W. Guo, H. H. Ngo et al., "A review on the occurrence of micropollutants in the aquatic environment and their fate and removal during wastewater treatment," Science of the Total Environment, vol. 473-474, pp. 619-641, 2014.

[36] M. Röhricht, J. Krisam, U. Weise, U. R. Kraus, and R.-A. Düring, "Elimination of carbamazepine, diclofenac and naproxen from treated wastewater by nanofiltration," Clean-Soil, Air, Water, vol. 37, no. 8, pp. 638-641, 2009.

[37] A. I. Schäfer, I. Akanyeti, and A. J. C. Semião, "Micropollutant sorption to membrane polymers: a review of mechanisms for estrogens," Advances in Colloid and Interface Science, vol. 164, no. 1-2, pp. 100-117, 2011.

[38] V. Yangali-Quintanilla, S. K. Maeng, T. Fujioka, M. Kennedy, Z. Li, and G. Amya, "Nanofiltration vs. reverse osmosis for the removal of emerging organic contaminants in water reuse," Desalination and Water Treatment, vol. 34, no. 1-3, pp. 50-56, 2011.

[39] L. S. Li, W. P. Zhu, P. Y. Zhang, P. Lu, Q. Y. Zhang, and Z. L. Zhang, "UV/O $\mathrm{O}_{3}$-BAC process for removing organic pollutants in secondary effluents," Desalination, vol. 207, no. 1-3, pp. 114124, 2007.
[40] B. S. Oh, Y. J. Jung, Y. J. Oh, Y. S. Yoo, and J.-W. Kang, "Application of ozone, UV and ozone/UV processes to reduce diethyl phthalate and its estrogenic activity," Science of the Total Environment, vol. 367, no. 2-3, pp. 681-693, 2006.

[41] A. J. Kumar and C. Namasivayam, "Uptake of endocrine disruptor bisphenol-A onto sulphuric acid activated carbon developed from biomass: equilibrium and kinetic studies," Sustainable Environment Research, vol. 24, no. 1, pp. 73-80, 2014.

[42] M. F. N. Secondes, V. Naddeo, F. J. Ballesteros, and V. Belgiorno, "Adsorption of emerging contaminants enhanced by ultrasound irradiation," Sustainable Environment Research, vol. 24, no. 5, pp. 349-355, 2014.

[43] C.-F. Chang, C.-Y. Chang, and T.-L. Hsu, "Preparation and adsorptive application of novel superparamagnetic zirconia material," Colloids and Surfaces A: Physicochemical and Engineering Aspects, vol. 327, no. 1-3, pp. 64-70, 2008.

[44] C.-F. Chang, C.-Y. Chang, and T.-L. Hsu, "Removal of fluoride from aqueous solution with the superparamagnetic zirconia material," Desalination, vol. 279, no. 1-3, pp. 375-382, 2011.

[45] J.-Y. Tseng, C.-Y. Chang, Y.-H. Chen, C.-F. Chang, and P.-C. Chiang, "Synthesis of micro-size magnetic polymer adsorbent and its application for the removal of $\mathrm{Cu}(\mathrm{II})$ ion," Colloids and Surfaces A: Physicochemical and Engineering Aspects, vol. 295, no. 1-3, pp. 209-216, 2007.

[46] J.-Y. Tseng, C.-Y. Chang, C.-F. Chang et al., "Kinetics and equilibrium of desorption removal of copper from magnetic polymer adsorbent," Journal of Hazardous Materials, vol. 171, no. 1-3, pp. 370-377, 2009.

[47] H. Kaczmarek, A. Podgórski, and K. Bajer, "Photochemical reactions in poly(vinyl chloride)/poly(vinyl alcohol) blends," Journal of Photochemistry and Photobiology A: Chemistry, vol. 171, no. 2, pp. 187-195, 2005.

[48] S. Majumdar and B. Adhikari, "Polyvinyl alcohol: a taste sensing material," Sensors \& Actuators B: Chemical, vol. 114, no. 2, pp. 747-755, 2006.

[49] A. S. Özcan, B. Erdem, and A. Özcan, "Adsorption of Acid Blue 193 from aqueous solutions onto BTMA-bentonite," Colloids and Surfaces A: Physicochemical and Engineering Aspects, vol. 266, no. 1-3, pp. 73-81, 2005. 

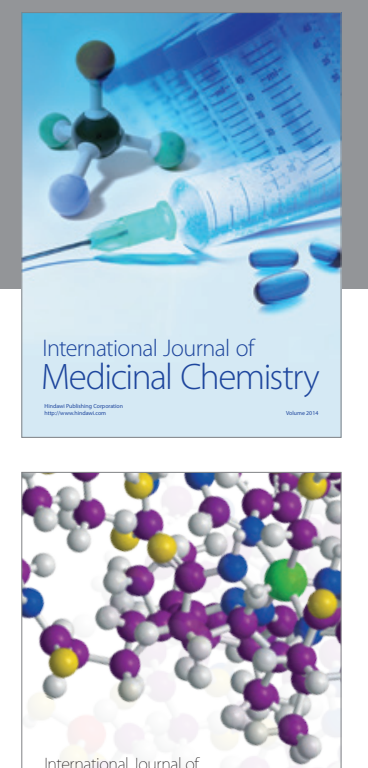

\section{Carbohydrate} Chemistry

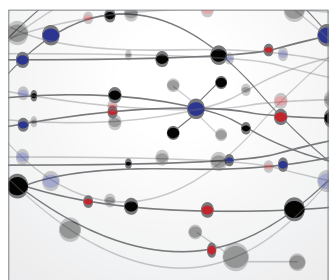

The Scientific World Journal
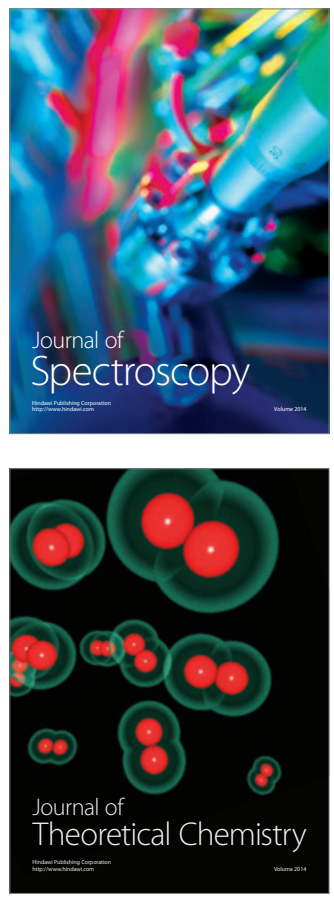
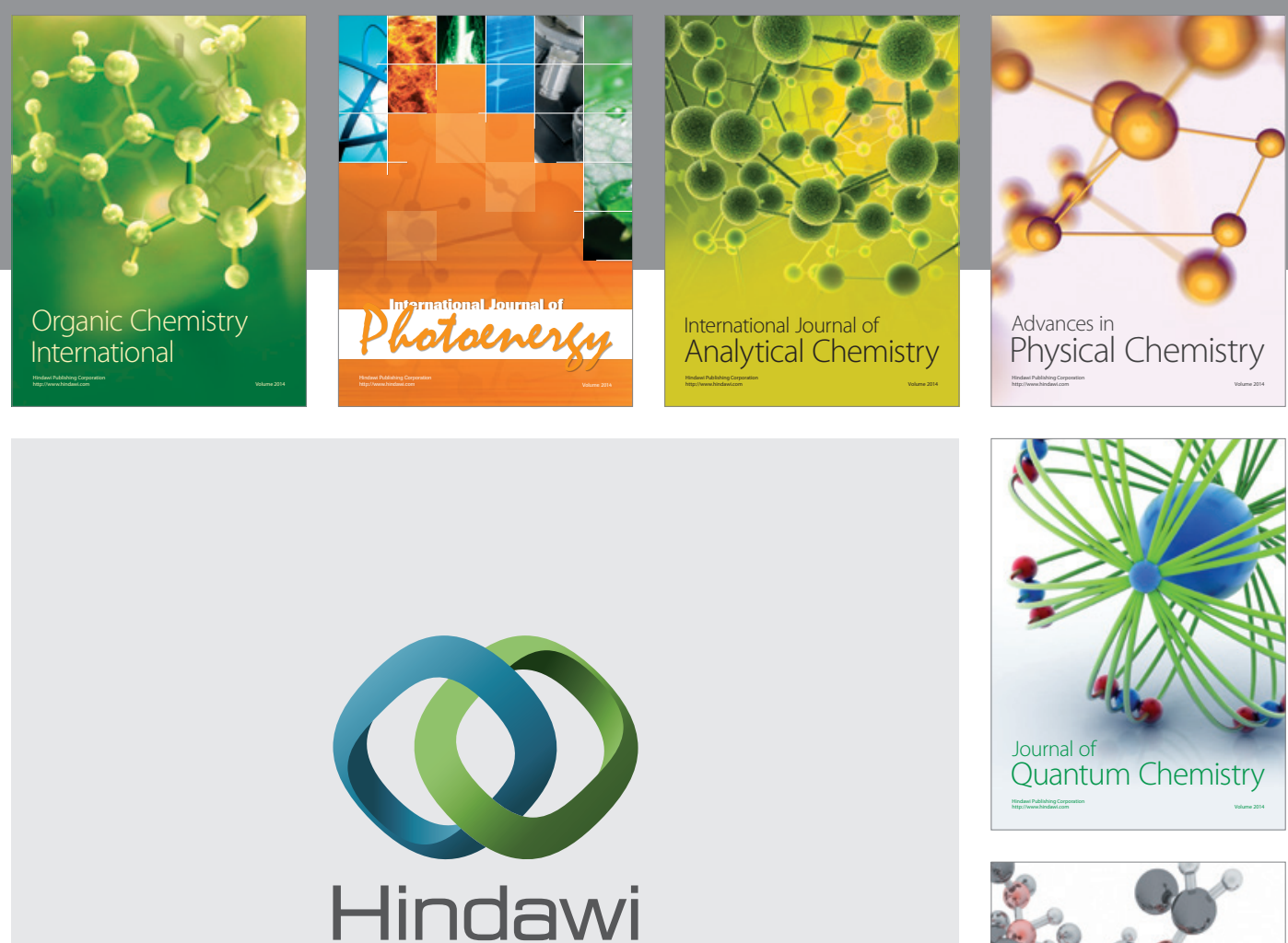

Submit your manuscripts at

http://www.hindawi.com

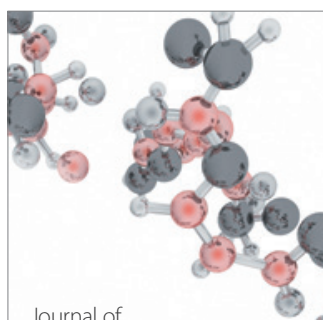

Analytical Methods

in Chemistry

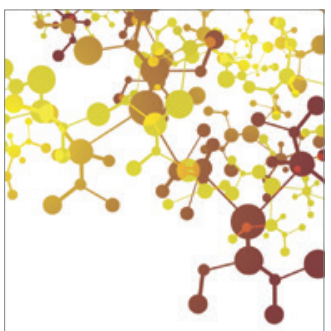

Journal of

Applied Chemistry

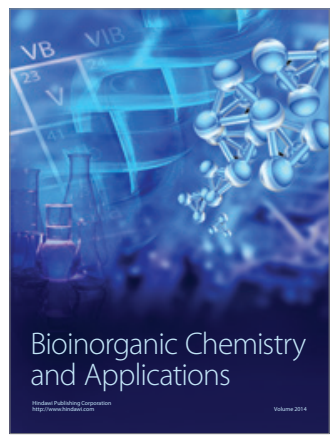

Inorganic Chemistry
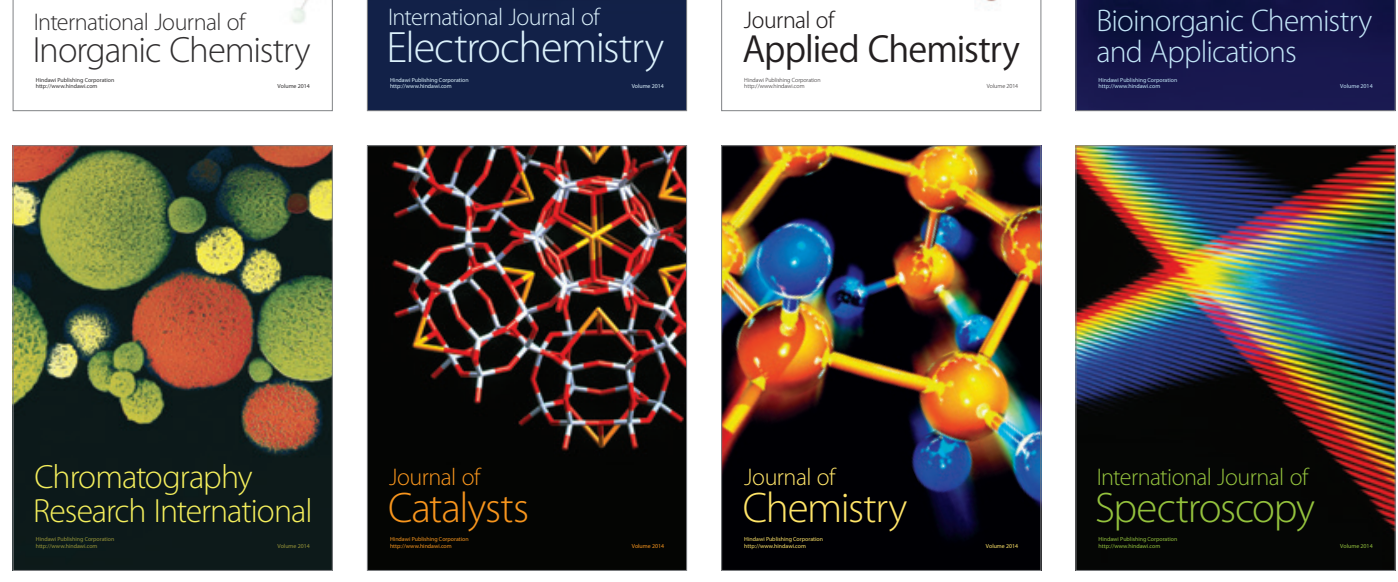